\title{
Incidence of Bemisia tabaci Gennadius (Aleyrodidae, Aleyrodinae) in four Atlantic Forest fragments
}

\author{
Ocorrência de Bemisia tabaci Gennadius (Hemiptera: \\ Aleyrodidae) em quatro fragmentos de Mata Atlântica
}

\author{
Thiago Dias Trindade ${ }^{*}$ (D), Henrique Trevisan ${ }^{1}$ (D), Acácio Geraldo de Carvalho ${ }^{1}$
}

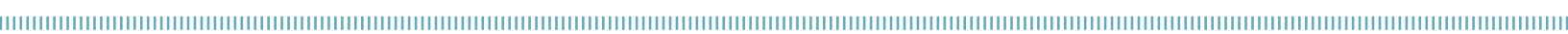

\begin{abstract}
Bemisia tabaci has been known in Brazil since 1923 , in cotton, soybean, tomato and bean crops, and it leads to economic losses due to the transmission of different viruses. Studies focused on analyzing the incidence of this pest in forest environments remain scarce in the literature. Thus, the aims of the current study were to investigate the incidence of $B$. tabaci in four Atlantic forest fragments in Rio de Janeiro state, Brazil, as well as to record its hosts in these environments. An area of approximately one hectare was delimited for each Atlantic forest fragment based on images provided by the Brazilian Institute of Geography and Statistics (IBGE). Plants presenting whiteflies were tagged throughout monthly inspections conducted in each forest fragment in order to be checked during the following visits. Collection criteria were adopted to assure sampling standardization in each fragment. The mean number of whiteflies was analyzed through the Kruskal-Wallis non-parametric test, which was followed by Dunn's post-hoc test, both at $5 \%$ significance level. The total of 216 collections were conducted and 1,126 B. tabaci fourth-instar nymphs were collected in four Atlantic forest fragments over 24 months. The following hosts were recorded for the first time: Caesalpinia pluviosa Benth, Tradescantia zebrina Linn., Impatiens walleriana Linn., Cupania sp. and Talisia esculenta Klotzsch \& O. Berg. The dry period (winter) enabled the increase of $B$. tabaci populations in the herein investigated forest fragments.
\end{abstract}

KEYWORDS: whitefly; forest fragments; pest.
RESUMO: Bemisia tabaci é conhecida no Brasil desde 1923, relatada em cultivos de algodão, soja, tomate e feijoeiro, promovendo prejuízos econômicos por ser transmissora de viroses. São praticamente inexistentes os trabalhos que analisam sua ocorrência em ambiente florestal. Nesse sentido, o objetivo deste trabalho foi estudar a ocorrência de $B$. tabaci em quatro fragmentos florestais de Mata Atlântica no estado do Rio de Janeiro, bem como registrar seus hospedeiros nesses ambientes. Em cada fragmento de Mata Atlântica foi demarcada uma área com cerca de um hectare, delimitada com o uso de imagens obtidas do Instituto Brasileiro de Geografia e Estatística (IBGE). Ao longo das inspeçôes mensais nos fragmentos florestais, os vegetais que apresentavam moscas-brancas foram marcados e inspecionados a toda nova visita. Adotaram-se critérios de coleta para garantir padronização do esforço amostral em todos os fragmentos. A análise do número médio de moscas-brancas foi feita pelo teste não paramétrico de Kruskal-Wallis, com posterior aplicação do pós-teste de Dunn, ambos a 5\% de significância. Foram realizadas 216 coletas e capturadas 1.126 ninfas de quarto instar de B. tabaci nos quatro fragmentos de Mata Atlântica ao longo dos 24 meses. Registraram-se, pela primeira vez, os hospedeiros: Caesalpinia pluviosa Benth, Tradescantia zebrina Linn., Impatiens walleriana Linn., Cupania sp. e Talisia esculenta Klotzsch \& O. Berg. O período seco (inverno) promove estímulos para o aumento da população de B. tabaci em fragmentos florestais.

PALAVRAS-CHAVE: mosca-branca; fragmentos florestais; praga. 


\section{INTRODUCTION}

Bemisia tabaci was first described as Aleyrodes tabaci on tobacco leaves in Greece. Additional 18 species were described until 1957, when specialists decided that there was a single taxon - B. tabaci. The species was classified as sporadic pest from 1926 to 1981, besides being vector of viral diseases in subtropical, tropical and even temperate climate zones (BROWN et al., 1995). According to PERRING et al. (1993), B. tabaci emerged as a global issue in the early 1980s, when biotype B, originally from the Middle East, was detected in several host plants in the United States of America and in Mexico, like: melon, tomato, lettuce, cotton, carrot, among others. There was also the likelihood of having the emergence of a new biotype given the nature of the attack (PERRING et al., 1993; BROWN et al., 1995; PERRING, 2001).

According to COSTA et al. (1975), this whitefly species has been known in Brazil since 1923. Nowadays, it is reported in cotton, soybean, tomato and bean crops, among others, besides causing significant economic losses due to transmission of different viruses (BARBOSA et al., 2011; OLIVEIRA et al., 2013; DE MARCHI et al., 2018). In the 1990s, severe $B$. tabaci infestations led to irregular fruit ripening in tomato crops due to the transmission of viral diseases (LOURENÇÃO; NAGAI, 1994). There was also intense biotype $B$ colonization in several plants (including spontaneous species) grown in São Paulo State, Brazil, and this whitefly species gradually spread to several states (LOURENÇÃO; NAGAI 1994). BELLOWS JUNIOR et al. (1994) initially classified the biotype $B$ as a new species - Bemisia argentifolii —, based on its smaller thoracic tracheal openings, on the smaller and more delicate wax filament, on the incidence of submarginal seta ASMS4, as well as on the nature of damages it caused to host plants. According to BROWN et al. (1995), B. tabaci biotype B was a vast complex undergoing biological changes (TAKAHASHI, 2005). DE BARRO et al. (2011) observed lack of reproductive compatibility between some biotypes and concluded that there was genetic divergence between biotypes found in the Brazilian central region and those recorded for other regions in the country. Nowadays, B. tabaci comprises more than 40 cryptic species (ELFEKIH et al., 2018; DE MARCHI et al., 2018); four of them were reported in Brazil, so far (DA FONSECA et al., 2015; MARUBAYASHI et al., 2013; DE MARCHI et al., 2018).

In light of the foregoing, the aims of the current study were to investigate the incidence of $B$. tabaci in four Atlantic forest fragments in Rio de Janeiro state, Brazil, as well as to record its hosts in these environments. images generated in Google Earth software and on the ones provided by the Brazilian Institute of Geography and Statistics (IBGE). Garmin global positioning system (GPS) was used to record the geographic coordinates of the forest fragments.

The collection procedure was based on CASSINO; RODRIGUES (2004), that observed the presence, or absence, of whiteflies in vegetable hosts growing in their sampling units. Plants presenting whiteflies were tagged throughout the monthly inspections carried out in each forest fragment in order to be inspected in the following visits. Proper collection criteria were applied to different plant types to assure sampling standardization in all the herein investigated sites. Plants presenting whiteflies in a square meter of plant material, and bushes up to $4 \mathrm{~m}$ tall, were divided in quadrants (North-South-East-West), according to CASSINO; RODRIGUES (2004). Five leaves were removed from each plant in their respective quadrants. Tree-sized plants were observed from the canopy skirt, and five random leaves were collected in quadrants; irregular-shaped or small-sized plants were randomly sampled based on the collection of five leaves. Leaves presenting whiteflies were packed in envelopes and sent to the Laboratory of the Universidade Federal Rural do Rio de Janeiro (UFRRJ) Technical School, where $4^{\text {th }}$-instar nymphs were counted and taxonomically identified. Unidentified botanical materials were sent to the Botany Department of UFRRJ.

Fourth-instar nymphs were removed from leaf blades with an entomological pin and mounted in glass slides using Hoyer's and/or Canada balsam medium. Slides were properly labeled with information such as host, collection site, date and collector. This procedure was adopted because the nymph (sessile) individuals were manually sampled, unlike trap-based strategies adopted to catch adult (moving) individuals. The herein collected $4^{\text {th }}$-instar nymphs were identified based on information provided by MOUND (1963) and MARTIN (2005).

A bar chart was generated based on the percentage of whiteflies collected in each forest fragment, whereas a line chart was generated to analyze the fluctuation in the whitefly population throughout two survey years. Data normality was checked through the Lilliefors test, whereas the mean number of individuals was subjected to analysis of variance in the Kruskal-Wallis non-parametric test, at 5\% significance level. Once significance was recorded, the Dunn's post-hoc test (at 5\% significance level) was used to analyze the mean ranks; significant differences were expressed through different letters followed by the true mean in bar charts.

Samples were collected in four forest fragments in Rio de Janeiro state: Teresópolis, Grajaú, Pedra Branca and Paulo de Frontin (Table 1).

\section{MATERIALS AND METHODS}

An area of approximately one hectare was delimited in each of the herein investigated Atlantic forest fragments, based on

\section{RESULTS AND DISCUSSION}

The total of 1,126 individuals were collected from four Atlantic forest fragments in Rio de Janeiro state and recorded. B. tabaci 
presented significant ability to occupy creeping plants such as Tradescantia zebrina, or tree species such as Caesalpinia pluviosa, grown in forest environments (Table 2). According to GALLO et al. (2002), this pest species is widespread in agricultural crops cultivated in Brazil; however, there is no information about its incidence in forest environments.

The forest fragment in Grajaú presented the most favorable environmental conditions to the incidence of whiteflies; thus, it recorded mean number of individuals (28) significantly higher than the ones of other monitored environments - Teresópolis (7.9), P. de Frontin (5.3) and Pedra Branca (4.1) —, in the Dunn's post-hoc test, at 5\% significance level (Fig. 1).

According to GILBERT et al. (1976), it is essential conducting studies about population dynamics to help developing pest-management plans, since monitoring insect populations throughout a predetermined length of time (ODUM, 1988) helps indicating their distribution, abundance and ecological interactions (BATALDEN et al., 2007). Thus, it is possible predicting the incidence of eventual outbreaks in order to suggest specific control measures (BATALDEN et al., 2007).

The literature lacks studies about the fluctuation of whitefly populations in forest fragments, except for the one conducted by HARTERREITEN-SOUZA et al. (2015), that analyzed the incidence of $B$. tabaci in several environments, two of them were forest fragments. However, there are several studies about whiteflies, mainly about B. tabaci, in agricultural environments. According to PAIVA; GOULART (1995), whitefly populations are bigger in Phaseolus vulgaris at the end of the hot season - when rainfall rates are lower
- than in other crops. In addition, the frequency of B. tabaci populations in $P$. vulgaris crops is linked to climate conditions, since this pest prefers high-temperature environments (PAIVA; GOULART, 1995).

There was sharp whitefly population increase in Grajaú fragment at late summer 2014 (often rainy season), and it decreased until early winter (dry season), when it rapidly increased again (Fig. 2). These findings corroborate the study by PAIVA; GOULART (1995), who observed increased abundance of $B$. tabaci in agricultural environments during the same period. However, besides the seasonal variation of environmental conditions, other factors may have influenced

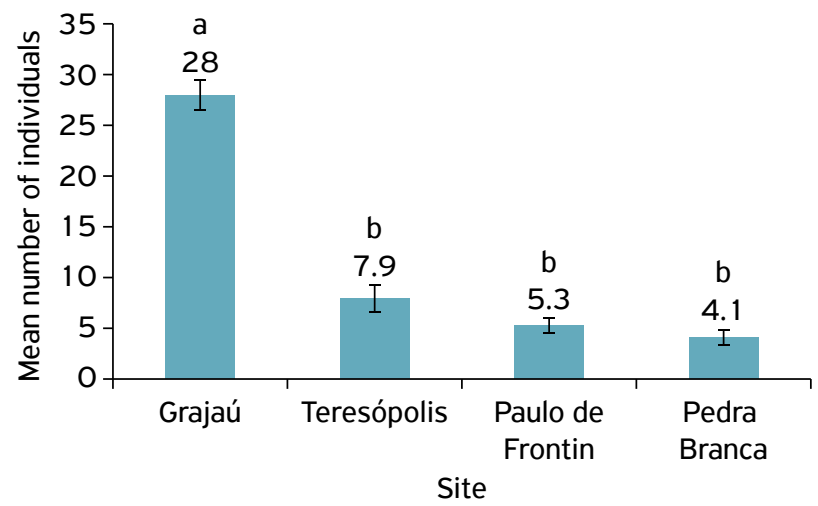

Means followed by different letters show statistically significant difference in the Dunn's post-hoc test at $5 \%$ significance level.

Figure 1. Mean number, and standard error, of Bemisia tabaci

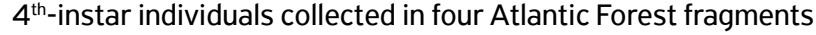
in Rio de Janeiro state, Brazil, from Jan/2014 to Dec/2015.

Table 1. Altimetry and geographic coordinates of the herein evaluated Atlantic Forest fragments.

\begin{tabular}{lccc} 
Fragment & Altitude $(\mathrm{m})$ & Latitude & Longitude \\
\hline Teresópolis & 1,235 & $22^{\circ} 15^{\prime} 21.39^{\prime \prime}$ & $42^{\circ} 44^{\prime} 25.26^{\prime \prime}$ \\
\hline Grajaú & 76 & $22^{\circ} 54^{\prime} 59.36^{\prime \prime}$ & $42^{\circ} 15^{\prime} 53.43^{\prime \prime}$ \\
\hline Pedra Branca & 158 & $22^{\circ} 57^{\prime} 42.55^{\prime \prime}$ & $43^{\circ} 28^{\prime} 29.06^{\prime \prime}$ \\
\hline Paulo de Frontin & 611 & $22^{\circ} 30^{\prime} 46.02 ”$ & $43^{\circ} 36^{\prime} 35.53^{\prime \prime}$ \\
\hline
\end{tabular}

Table 2. Bemisia tabaci hosts found in the herein evaluated Atlantic forest fragments.

\begin{tabular}{lccccc} 
Host & Family & Size & \multicolumn{2}{c}{ Collection site } & Origin \\
Caesalpinia pluviosa Benth & Fabaceae & Tree & Grajaú & Native \\
\hline Tradescantia zebrina Linn. & Commelinaceae & Herb & Grajaú & Native \\
\hline Impatiens walleriana Linn. & Balsaminaceae & Herb & Teresópolis & Native \\
\hline Mimosa caesalpiniifolia Benth & Fabaceae & Tree & Grajaú & Native \\
\hline Myrcia sp. & Myrtaceae & Shrub & Tijuca Forest, Paulo de Frontin & Native \\
\hline Psidium sp. & Myrtaceae & Shrub & Pedra Branca & Native \\
\hline Psidium guajava Linn. & Myrtaceae & Tree & Grajaú & Native \\
\hline Talisia esculenta Klotzsch \& O. Berg & Sapindaceae & Tree & Grajaú & Native \\
\hline
\end{tabular}


B. tabaci populations in the herein investigated forest fragments. Rainfall may have been one of these factors; according to SILVA et al. (2008), it works as natural whitefly regulating agent, since it influences adult mortality through the mechanical action of raindrops and sets a favorable microclimate for the action of predators, parasitoids and entomopathogens.

In addition, wildfires such as the ones often seen in Grajaú fragment can increase plant stress, which is an attractive condition for several phyllophagous species. Wildfires may also have contributed to increase the whitefly population during the months after September, since these events were recorded in the aforementioned forest fragment until December 2015. Consequently, GILL (1990) observed that adverse environmental conditions such as wildfires can favor the expansion of whitefly populations in different host plants. According to WHITE (1984), stressed plants are more vulnerable to pest attacks, because they are richer in nutrients and less protected by chemical defenses. In view of that, it is possible suggesting that the whitefly population observed in Grajaú fragment found favorable establishment conditions. On the other hand, in agreement with HARTERREITEN-SOUZA et al. (2015), forest fragments surrounded by urban areas disfavor the dispersion flow of large whitefly populations and lead to smaller population outbreaks of this pest. Their observation differs from our findings, since Grajaú fragment presented the largest whitefly populations although it had the largest area surrounded by urban characteristics.

The fragment studied by HARTERREITEN-SOUZA et al. (2015) may not have presented some factors capable of stimulating the establishment of whiteflies, such as people flow and the introduction of exotic plant species; however, these factors were found in Grajaú fragment. In addition, the aforementioned area can be possibly seen as an open habitat, although it looks like a forest fragment, because of successive ecological disturbances characteristic of agricultural crop areas, besides presenting host plants capable of enabling excellent developmental conditions for whiteflies.

Based on the comparison between the number of B. tabaci individuals observed in the current study and the one reported by HARTERREITEN-SOUZA et al. (2015) in five different environments in the Cerrado biome, it is possible seeing population pattern similarities only in Grajaú fragment (Fig. 2), where summer conditions enabled the largest $B$. tabaci population in 2014. On the other hand, B. tabaci populations found in the other fragments investigated in the current study throughout 2014 and 2015 achieved their peak in other seasons, mainly in winter, as it became evident in 2015 (Fig. 2). This finding disagrees with analyses conducted by HARTERREITENSOUZA et al. (2015), who showed that summer was the most favorable season for whitefly population increase. Thus, it is necessary clarifying that many hypotheses can be adopted to explain differences in insect population patterns in different environments, such as sampling strategy, plant features, climate, atmospheric conditions, anthropization level, the use of pesticides, among others (GATEHOUSE, 1997). It is worth emphasizing that HARTERREITEN-SOUZA et al. (2015) mostly conducted their study in the Cerrado biome and in agricultural environments. Consequently, it is possible

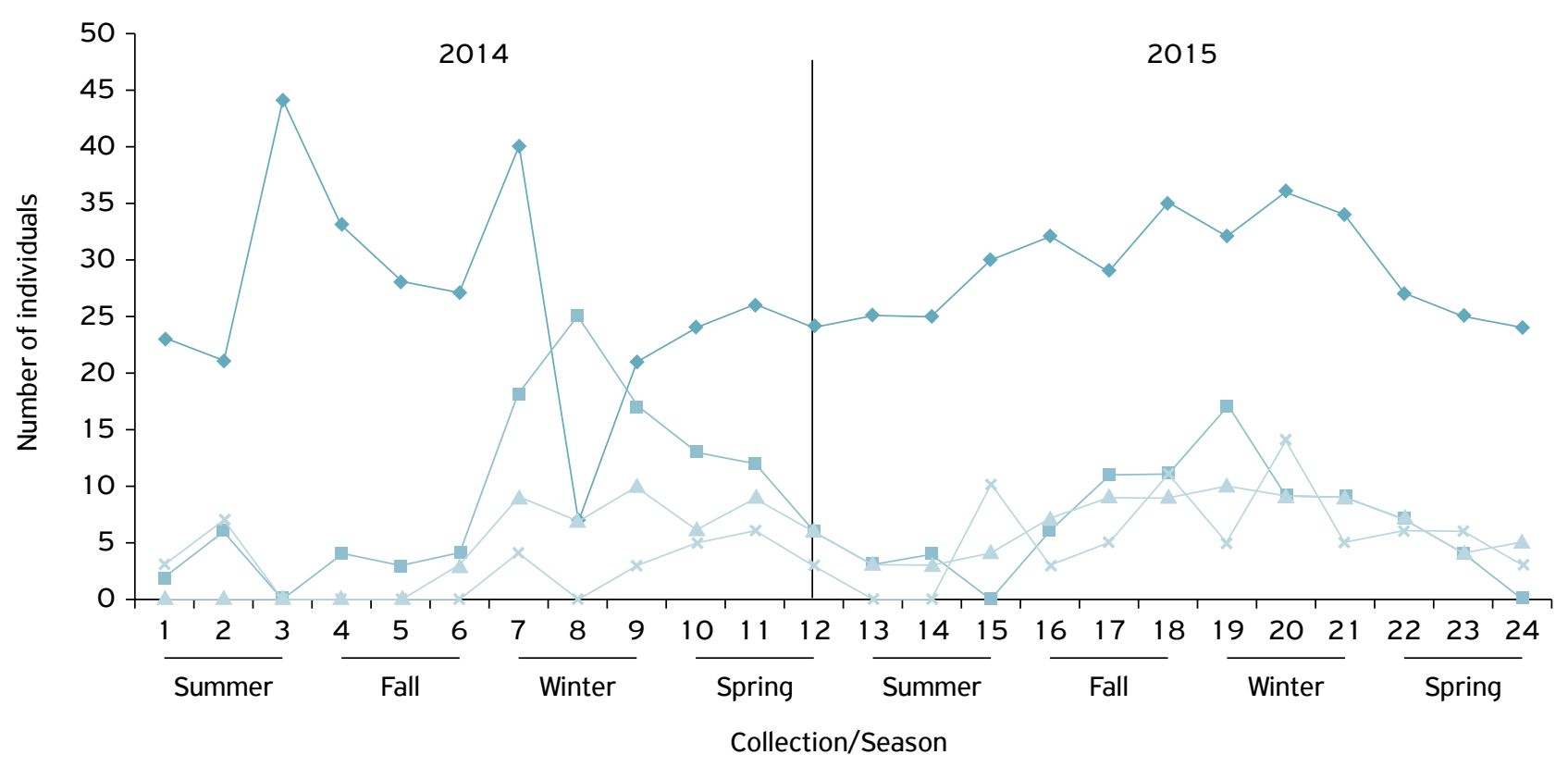

$\longrightarrow$ Grajaú $\longrightarrow$ Teresópolis $\quad \longrightarrow$ Paulo de Frontin $\quad x$ Pedra Branca

Figure 2. Fluctuation in Bemisia tabaci 4th-instar-nymph population in four Atlantic forest fragments in Rio de Janeiro state, Brazil, from Jan/2014 to Dec/2015. 
suggesting that these characteristics may explain differences between the seasonality of $B$. tabaci populations found in the forest fragments investigated in the current study and that observed by HARTERREITEN-SOUZA et al. (2015). Therefore, complementary studies are necessary in order to clarify the hypotheses herein raised for $B$. tabaci.

B. tabaci populations found in Pedra Branca and Teresópolis fragments started increasing at the beginning of the dry period in 2014; however, they decreased at the peak of this period (Fig. 2). There was a wildfire event in Pedra Branca fragment, whereas Teresópolis fragment did not suffer any environmental damage in that year. Teresópolis fragment is next to an agricultural (vegetables) production unit that covers approximately seven hectares. During a survey conducted in the aforementioned unit, it was possible observing that $B$. tabaci systematically infested vegetable crops, fact that required adopting phytosanitary measures to control this pest. According to RIIS; NACHMAN (2006), the abundance of whiteflies, mainly of $B$. tabaci, can be affected by the dispersion of surrounding habitats, or even by populations that migrate to long distances, either carried by the wind or transported through other vectors. There may have transit between $B$. tabaci populations living in the forest fragment in Teresópolis and those of the agricultural production unit, which can be the species-permanence factor in both places, if one takes into consideration that the aforementioned forest fragment is not subjected to any management procedure. With respect to the whitefly migration hypothesis, based on GATEHOUSE (1997), the colonization of new areas is a slow process due to the small size of whiteflies, and the short distances covered by them; however, when the aforementioned author addressed the displacement of whiteflies, he only focused on the plants they moved to. Thus, it is possible assuming that whitefly dispersal in anthropized forest fragments is higher than that of agricultural crops due to conditions enabled by forest environments; among them, one finds shelter from inclement weather conditions and lack of phytosanitary interventions, which could favor the flight and the establishment of this pest.

HARTERREITEN-SOUZA et al. (2015) conducted a study with different fragment compositions and collected a number of whiteflies far larger than the one recorded in the current study, due to the sampling type adopted by them. They observed that $95 \%$ of the captured specimens were concentrated in two areas close to properties that cultivated soybean and bean monocultures, which are known to host whiteflies. Therefore, these crops may have influenced the population expansion of these insects. Assumingly, the increase in B. tabaci populations in the four herein investigated forest fragments in 2015 (Fig. 2) may have happened because the prolonged drought that took place in Brazil, mainly in Rio de Janeiro state, and the low physiological resistance of the plant, which enabled species $B$. tabaci to spread rapidly. This hypothesis was confirmed by the decrease in $B$. tabaci populations in the spring (beginning of the rainy season), when there were some heavy rain events, except for Paulo de Frontin fragment, which is routinely subjected to forest maintenance procedures such as sanitary pruning and the planting of new species indicated to the biome, unlike the other fragments. Overall, despite the forest management applied to Paulo de Frontin fragment, all forest fragments presented similar pattern in the fluctuation of B. tabaci populations, except for Grajaú, which presented significant difference in such pattern, probably because it was the most anthropized fragment and the one exposed to more ecological disturbances than the other fragments.

Nova Friburgo and Teresópolis were the only fragments, among the ones evaluated in the current study, located at more than $1,000 \mathrm{~m}$ of altitude $-1,170$ and $1,235 \mathrm{~m}$, respectively; Teresópolis fragment recorded incidence of $B$. tabaci. According to MORALES; JONES (2004), B. tabaci does not adapt well to altitudes higher than $1,000 \mathrm{~m}$, besides being always associated with agricultural environments. The aforementioned authors pointed out that this whitefly species is not found in altitudes higher than $1,000 \mathrm{~m}$. On the other hand, the analysis applied to the information presented by these authors allowed seeing that the investigated fragment was very close to an agricultural system, as well as that the ecological characteristics of both the fragment and the agricultural system can contribute to the establishment of small B. tabaci populations, even at altitudes seen as adverse for such establishment, according to MORALES; JONES (2004). Assumingly, altitude can influence other whitefly species; such hypothesis can be checked in future studies.

According to HARTERREITEN-SOUZA et al. (2015), there was only $1 \%$ contribution of $B$. tabaci individuals from native forests in comparison to agricultural areas, fact that helps explaining the low quantitative value recorded for this species in the fragments sampled by them. However, the sampling method adopted in the current study and the one selected by HARTERREITEN-SOUZA et al. (2015) were widely different, since our study was focused on collecting $4^{\text {th }}$-instar nymphs, whereas HARTERREITEN-SOUZA et al. (2015) collected adult whiteflies in the Cerrado biome using colored traps.

B. tabaci often takes Mimosa caesalpiniaefolia as host; this legume species was widely spread in Grajaú fragment and it was one of the hosts that most presented whiteflies species such as B. tabaci, Aleurotrachelus atratus and Aleurothrixus floccosus in the current study. M. caesalpiniifolia is widely used in reforestation processes, besides having other applications such as feeding animals, landscaping, sawmilling, medicinal use, among others (CARVALHO, 2007). M. caesalpiniifolia was already investigated as potential B. tabaci controller. CAVALCANTE et al. (2006), among other plant species with high tannin levels, studied the use of plant extracts from M. caesalpiniifolia to control B. tabaci. However, the extract from these plant species did not lead to egg infeasibility or significantly affected the biological cycle of $B$. tabaci. High B. tabaci concentrations were observed in leaves of this host, which triggered phytotoxicity 
symptoms in the leaflets. Altitude is another factor that may have favored whitefly populations in Grajaú fragment. According to MORALES; JONES (2004), B. tabaci does not adapt well to altitudes higher than $1,000 \mathrm{~m}$; thus, it is likely that other whitefly genera and species present similar behavior.

\section{CONCLUSIONS}

Whitefly species Bemisia tabaci was recorded for the first time on plant species such as Cupania sp., Impatiens walleriana,
Talisia esculenta, Tradescantia zebrina and Caesalpinia pluviosa grown in an Atlantic forest fragment. Grajaú forest fragment was the environment presenting the most favorable conditions for the establishment of the herein investigated whitefly species. The dry season (winter) provides stimuli for $B$. tabaci populations to increase in forest fragments. The environmental conditions in 2015 provided the most favorable conditions for the establishment of $B$. tabaci in the herein evaluated forest fragments in comparison to 2014. Further studies about the ecological role played by whiteflies in forest fragments should be carried out to help improving the knowledge about this economically important group of species.

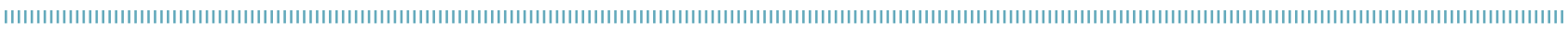
REFERENCES

BARBOSA, J.C.; BARRETO, S.S.; INOUE-NAGATA, A.K.; REZENDE, J.A.M. Characterization and experimental host range of a Brazilian tomato isolate of Tomato severe rugose virus. Journal of Phytopathology, v.159, n.9, p.644-646, 2011 . https://doi. org/10.1111/j.1439-0434.2011.01817.x

BATALDEN, R.V.; OBERHAUSER, K.; PETERSON, A.T. Ecological niches in sequential generations of Eastern North American Monarch Butterflies (Lepidoptera: Danaidae): The ecology of migration and likely climate change implications. Environmental Entomology, College Park, v.36, n.6, 1365-1373, 2007. https:// doi.org/10.1603/0046-225X(2007)36[1365:ENISGO]2.0.CO;2

BELLOWS JUNIOR, T.S.; PERRING, T.M.; GILL, R.J.; HEADRICK, D.H. Description of a species of Bemisia (homoptera: Aleyrodidae). Annals of the Entomological Society of America, New York, v.87, n.2, p.195-206, 1994. https://doi.org/10.1093/aesa/87.2.195

BROWN, J.K.; FROHLICH, D.R.; ROSELL, R.C. The sweetpotato or silverleaf whiteflies: biotypes of Bemisia tabaci or a species complex? Annual Review of Entomology, Palo Alto, v. 40, n. 1, 511-534, 1995. https://doi.org/10.1146/annurev. en.40.010195.002455

CARVALHO, P.E.R. Sabiá - Mimosa caesalpiniifolia. Colombo: EMBRAPA Florestas, 2007. 10p. (Circular Técnica 135).

CASSINO, P.C.R.; RODRIGUES, W.C. Monitoramento de insetos fitófagos, ácaros e inimigos naturais. In: CASSINO, P.C.R.; RODRIGUES, W.C. (coords.). Citricultura fluminense: Principais pragas e seus inimigos naturais. Seropédica: EDUR, 2004. p.149- 157.

CAVALCANTE, G.M.; MOREIRA, A.F.C.; VASCONCELOS, S.D. Potencialidade inseticida de extratos aquosos de essências florestais sobre mosca-branca. Pesquisa Agropecuária Brasileira, Brasília, v.41, n.1, p.9-14, 2006. http://dx.doi.org/10.1590/ so $100-204 \times 2006000100002$

COSTA, A.S.; OLIVEIRA, A.R.; SILVA, D.M. Transmissão mecânica do mosaico dourado do tomateiro. Revista da Sociedade Brasileira de Fitopatologia, Brasília, v.6/7/8, p.147, 1975.
DA FONSECA, B.L.; YUKI, V.A.; MARUBAYASHI, J.M.; DE MARCHI, B.R.; PERINI, F.L.; PAVAN, M.A.; DE BARROS, D.R.; GHANIM, M.; MORIONES, E.; NAVAS-CASTILLO, J.; KRAUSE-SAKATE, R. First report of Bemisia tabaci Mediterranean (Q biotype) species in Brazil. Pest Management Science, v.71, n.4, p.501-504, 2015. https://doi.org/10.1002/ps.3909

DE BARRO, P.J.; LIU, S.S.; BOYKIN, L.M.; DINSDALE, A.B. Bemisia tabaci: A statement of species status. Annual Review of Entomology, Palo Alto, v.56, n. 1, p. 1-19, 2011 . https://doi.org/1010.1146/ annurev-ento-1 12408-085504

DE MARCHI, R.B.; KINENE, T.; WAINAINA, M.J.; KRAUSE-SAKATE, R.; BOYKIN, L. Comparative transcriptome analysis reveals genetic diversity in the endosymbiont Hamiltonella between native and exotic populations of Bemisia tabaci from Brazil. PLOS ONE, v.13, n.7, p.e0201411. https://doi.org/10.1371/ journal.pone.0201411

ELFEKIH, S.; TAY, W.T.; GORDON, K.; COURT, L.; DE BARRO, P. Standardized molecular diagnostic tool for the identification of cryptic species within the Bemisia tabaci complex. Pest Management Science, v.74, n.1, p.170-173, 2018. https://doi.org/10.1002/ps.4676

GALLO, D.; NAKANO, O.; SILVEIRA NETO, S.; CARVALHO, R.P.L.; BAPTISTA, G.C.; BERTI FILHO, E.; PARRA, J.R.P.; ZUCCHI, R.A.; ALVES, S.B.; VENDRAMIM, J.D.; MARCHINI, L.C.; LOPES, J.R.S.; OMOTO, C. Entomologia Agrícola. Piracicaba: Fundação de Estudos Agrários Luiz de Queiroz, 2002. 920p. (Biblioteca de Ciências Agrárias Luiz de Queiroz, v.10).

GATEHOUSE, A.G. Behavior and ecological genetics of wind-borne migration of insects. Annual Review of Entomology, v.42, 475-502, 1997. http://dx.doi.org/10.1 146/annurev.ento.42.1.475

GILBERT, N.; GUITIERREZ, A.P.; FRAZER, B.D.; JONES, R.E. Ecological relationships. San Francisco: W. H. Freeman, 1976. 256p.

GILL, R.J. The morphology of whitelies. In: GERLING, D. (ed.). Whiteflies: their bionomics, pest status and management. Intercept: Andover, 1990. p.13-46. 
HARTERREITEN-SOUZA, E.S.; PIRES, C.; SOARES, S.; MACHADO, L.; ARAÚJO, L.; PEREIRA, K.; SOUSA, V.; CORTES, A.A.T.; FONTES, E.M.G.; SUJII, E.R. Abundância e flutuação populacional da moscabranca em relação a padrões regionais e locais de fisionomia agrícola no Distrito Federal. Brasília, DF: Embrapa Recursos Genéticos e Biotecnologia, 2015. 28p.

LOURENÇÃO, A.L.; NAGAI, H. Surtos populacionais de Bemisia tabaci no estado de São Paulo. Bragantia, Campinas, v.53, n.1, p.53-59, 1994. http://dx.doi.org/10.1590/ S0006-87051994000100006

MARTIN, J.H. The Whiteflies of Belize (Hemiptera: Aleyrodidae) Part 2 - a review of the subfamily Aleyrodinae Westwood. Zootaxa, v. 1098, p. $1-100,2005$.

MARUBAYASHI, J.M.; YUKI, V.A.; ROCHA, K.C.G.; MITUTI, T.; PELEGRINOTTI, F.M.; FERREIRA, F.Z. At least two indigenous species of the Bemisia tabaci complex are present in Brazil. Journal of Applied Entomology, 2013, v.137, n.1-2, p.113-121, 2013. https://doi.org/10.1111/j.1439-0418.2012.01714.x

MORALES, F.J.; JONES, P.G. The ecology and epidemiology of Whiteflies - transmitted viruses in Latin America. Virus Research, v.100, n.1, p.57-65, 2004. https://doi.org/10.1016/j. virusres.2003.12.014

MOUND, L.A. Host-correlated variation in Bemisia tabaci (Gennadius) (Homoptera: Aleyrodidae). Proceedings of the Royal Entomological Society of London, v.38, n.10-12, p.171-180, 1963. https:// doi.org/10.1111/j.1365-3032.1963.tb00746.x

ODUM, E.P. Ecologia. Rio de Janeiro: Guanabara, 1988. 434p.

OLIVEIRA, C.M.; AUAD, A.M.; MENDES, S.M.; FRIZZAS, M.R. Economic impact of exotic insect pests in Brazilian agriculture.
Journal of Applied Entomology, v.137, n.1-2, p.1-15, 2013. https://doi.org/10.1111/jen.12018

PAIVA, F.A.; GOULART, A.C.P. Flutuação populacional da mosca-branca e incidência do mosaico dourado do feijoeiro em Dourados, MS. Fitopatologia Brasileira, Brasília, v.20, n.2, p.199-202, 1995.

PERRING, T.M.; COOPER, A.D.; RODRIGUEZ, R.J.; FARRAR, C.A.; BELLOWS JUNIOR, T.S. Identification of a whitefly species by genomic and behavioral studies. Science, Washington, v.259, n.5091, p.74-77, 1993. http://dx.doi.org/10.1126/science.8418497

PERRING, T.M. The Bemisia tabaci bv species complex. Crop Protection, London, v.20, n.9, p.725-737, 2001. http://dx.doi. org/10.1016/s0261-2194(01)00109-0

RIIS, L; NACHMAN, G. Migration, trapping and local dynamics of whiteflies (Homoptera: Aleyrodidae). Agricultural and Forest Entomology, v.8, n.3, p.233-234, 2006. https://doi. org/10.1111/j.1461-9563.2006.00302.x

SILVA, P.H.S.; CARNEIRO, J.S.; CASTRO, M.J.P. Manejo da mosca branca do cajueiro com óleos vegetais. Teresina: EMBRAPA, 2008. 6p. (Circular Técnica 47).

TAKAHASHI, K.M. Aspectos biológicos e potencial de parasitismo de Encarsia formosa (GAHAN) (Hymenoptera: aphelinidae) sobre Bemisia tabaci biótipo B (Gennadius) (Hemiptera: Aleyrodidae) em couve, tomate e soja. 2005. 73p. Thesis (Doutorado em Ciências: Entomologia) - Escola Superior de Agricultura "Luiz de Queiroz”, Universidade de São Paulo, Piracicaba, 2005. http:// dx.doi.org/10.1 1606/T.1 1.2005.tde-21062005-135251

WHITE, T.C.R. The abundance of invertebrate herbivores in relation to the availability of nitrogen in stressed food plants. Oecologia, v.63, n. 1, p.90-105, 1984. http://dx.doi.org/10.1007/BF00379790 